\title{
CHANGING GEO-POLITICAL DYNAMICS AND RUSSIA-PAKISTAN RELATIONS
}

DOI: 10.31696/2227-5568-2020-02-143-151

\begin{abstract}
The article examines the common tendency of the regional integration in the foreign policies of Russia and Pakistan marked by the enhancement of their bilateral relations in the rapidly changing global and regional environment. Their cooperation has been gradually reaching a new level of mutually beneficial partnership as a reflection of Moscow and Islamabad recent involvement in the undertaken formation of the joint economic and security structure of the emerging Greater Eurasia.
\end{abstract}

Key Words: BRI, CPEC, EAEU, GEP, SCO, Pakistan, Russia.

In our dynamically changing world there is political and economic shift towards the fast-growing Asia, which has a huge, but still not wholly used potential of human and natural resources. The proclaimed initiative by the Russian President Vladimir Putin to build "Greater Eurasian Partnership" (GEP, 2015) on this world's biggest continent with the inclusion in it along Russia such states, as China, India, Iran, Pakistan and other regional countries on the base of their existing cooperation structures (Eurasian Economic Union EAEU, Shanghai Cooperation Organization - SCO, Association of Southeast Asian Nations -ASEAN) may be viewed as an evident example in this context [1]. Actually, the conceptual framework of such a constructive partnership reflects the current trend towards regionalization in the foreign policy of all these states. Thus, for instance, the idea of geopolitical and geo-economic unity of the vast Central Eurasian territories permits to designate Russia as its Northern polar, Pakistan - as the Southern one, and China and Iran respectively - as the Eastern and Western poles. These four countries account for about $17 \%$ of the global GDP. Their multidimensional cooperation may not only contribute to the growth of their connectivity (transport, energy, military-technical, humanitarian, etc.), but to the sustainable inclusive socio-economic development with the aim of reducing tension and achieving peace in the region.

This quadrangular states configuration in their interaction appears to be quite natural and may be rather promising especially in the current scenario of deteriorating relations of all these countries with President Donald Trump's administration in Washington. The USA recent increase of economic, political and diplomatic pressure on all these states serves for the promotion of closer relations between Moscow, Islamabad, Beijing and Teheran. It may help to extend their interstate cooperation both on bilateral and quadrilateral levels,

* Serenko Irina N. - PhD (Education), Senior Research Scholar of IOS RAS. 
as well as on a multilateral basis within the framework of various international and regional platforms, including United Nation Organization and its specialized agencies, Shanghai Cooperation Organization, etc. In fact, Trump's policy helps to actualize the Russian concept of the "Greater Eurasian Partnership".

Among the most interested actors in the formation of this regional interstate cooperation may be, first of all, the Russian Federation (RF) and the Islamic Republic of Pakistan (IRP) with their current efforts to catch up for the lost in the past opportunities to built their mutually beneficial cooperation. According to the jointly conducted studies by domestic and foreign scholars on the evolution of these two countries relations during more than 70 years of their interstate development, there were numerous ups and downs in Moscow and Islamabad interaction throughout this turbulent period [2]. Recently their bilateral relations has been gradually reaching a new level of mutually beneficial partnership as a reflection of both states involvement in the undertaken creation of the joint economic and security structure of the Greater Eurasia. Their progress on this track is facilitated by the coordinated implementation of the Russian integration project of EAEU, which opens the prospect to create the Greater Eurasian Partnership, with the Chinese mega initiative One Belt, One Road (OBOR, 2013), renamed as Belt and Road Initiative (BRI, 2016), the flagship project of which is the China-Pakistan economic corridor (CPEC, 2015).

In this context Russia also appreciates the Pakistani side initiative (2010), which has been recently under discussion by its expected stakeholders, to establish a new strategic economic unit, the so called "Golden Ring Economic Bloc" (GREB) consisting, besides Russia and Pakistan, of China, Iran and Turkey. Its think-tank Centre for the strategic economic policy development - "Golden Ring Economic Forum" (GREF) was opened in Lahore (2015). Almost over $30 \%$ of the total human and natural resources belong to these five countries which geographically form a kind of a ring around Central Asia and Afghanistan determining the name of GREB [3]. Thus, different GREB aspects covering regional peace and stability for the economic security of engaged in this project countries were at the center of their business, diplomatic, defense and political circles attention during the International seminar in Islamabad. It was held on April 30, 2019 at the Pakistan Institute of Parliamentary Services. While sharing his views on the recent "sustainable positive trend" in different spheres of the Russia-Pakistan interaction (people-to-people contact, business-to-business ties, economic and cultural relations), the Trade Representative of RF in Pakistan Y. Kozlov underlined the importance "to expand such humanitarian and economic cooperation on a wider range. So from this standpoint the activity in the frameworks of the Gold Ring Economic Forum is appreciable" [4]. On the other hand, the Acting Ambassador of China in Pakistan Zhao Lijian while also supporting GREB initiative as "an innovative idea", still views it more as a long term project which complements the narrative of 
BRI and CPEC aimed similarly at "economic prosperity of the people of these five countries of Golden Ring" [5].

Being a private Pakistani entity, GREF members are represented by businessmen, different industrialists, ex-servicemen, former diplomats and scholars. One of GREF founding members and its Board of Governors Shahid Hassan (a post-graduate student from the Peoples ' Friendship University of Russia in Moscow during the former Soviet Union) visited on February 12, 2020 the Institute of Oriental Studies Russian Academy of Sciences (IOS RAS), so as to arrange the joint Pakistan-Russia research on GREB activities and its prospects. It was agreed by the participants of this working meeting under the head of Professor V. Y. Belokrenitsky to held GREF members roundtable discussion with the Russian experts from the Pakistan Study Sector of the IOS RAS Near and Middle East Department on March 2020, but due to the COVID-19 pandemic it was delayed for an indefinite period of time.

Actually, GREB concept initiated by the Pakistani side being strategically promising and beneficial for all the stakeholders seems to be one more targeted attempt of self-advertising the geostrategic importance of this Islamic State for the regional connectivity and Eurasian integration in the rapidly changing global and regional environment. But in reality, this project right now looks to be rather complicated for practical implementation due to the various reasons aggravated by the recent pandemic with the global economic crises. It includes, for instance, the rising US-China tensions in the contrast to the establishing US-India closer relations and the ongoing Iran-Saudi Arabia confrontation with their negative impact on Pakistan bilateral relations with all these states by adding greater strategic imbalance in the regional environment, not to say about continuous Pakistan-India tense stand-off over Kashmir or current China-India stand-off over their border dispute, as well as a much-delayed peace process in the neighboring Afghanistan.

But in any case, the emergence of GREB initiative as a national geostrategic and geo-economic concept of self-identification illustrates Islamabad intentions to turn its foreign policy in the relevant vector of regional integration by framing a new variation of regional economic bloc which is not in contradiction, but in supplement to the existing national Russia and China inclusive economic projects of Eurasia integration (GEP-EAEU and BRI-CPEC), so as to harmonies all of them. The increasing interest in the world, including Russia, to the dynamically developing, but least integrated Central Eurasian region is determined by the process of transport and energy connectivity between the states located along the currently revived ancient Great Silk road. The Chinese mega initiative BRICPEC was also supported by Moscow due to its convergence with the Russian project of GEP-EAEU. It provides an opportunity to create a broader partnership in Eurasia and to attain more extensive continental regionalization. That's why Russia views positively the option of CPEC further expansion by means of 
inclusion in it, besides Afghanistan (neighboring to China and Pakistan) the Islamic Republic of Iran, which is an important factor in stabilizing the situation in the Central and South Asia. The formation of a strategic partnership of these states within the framework of CPEC can contribute not only to their socio-economic growth, but to the stability in the region as well [6].

CPEC expansion and implementation are in the interests of Moscow primarily as an option to increase regional connectivity in Greater Eurasia. According to Pakistani experts, Russia "values Pakistan`s geographical location and desires to assist Pakistan in its peaceful integration into the multipolar Eurasian framework being constructed by Sino-Russian strategic cooperation. Within this framework, the multimodal CPEC currently provides the best opportunity to link Eurasia with South Asia" [7]. Besides it gives Moscow an opportunity to enter the new Asian gas supply markets viewed by the Russian energy superpower as an alternative to the European gas flow. With putting into operation all CPEC industrial and other projects there will be a significant increase in the energy consumption in which Pakistan has constantly experienced a big deficit.

The intensification of bilateral cooperation between Moscow and Islamabad in trade, economic, military-technical and other fields was promoted by the Russia-Pakistan agreement on the settlement of mutual financial claims and commitments on operations of the former Soviet Union with IRP. It was signed on December 2, 2019. In accordance to this document, Pakistan on February 26, 2020 paid of its debt to Russia in the amount of \$93.5 million dollars [8]. This opened an opportunity for the Russian Federation (the successor of the USSR) to launch the investment process in various sectors of Pakistan economy. While stressing the importance of removing this practically the last hurdle in the development of mutually beneficial economic cooperation, the Ambassador of IRP to the RF Shafqat Ali Khan, who arrived in Moscow for diplomatic work on March 22, 2020, confirmed the intentions of Pakistan leadership to "invest much more in one of our top priorities in our foreign policy - strong relations with Russia", which he considers to be at the moment "at the historically strongest point" [9].

It is evident, that Pakistan, which occupies an important geostrategic position in the Asian macro region with the access to the South seas and a huge human potential (population of 220 million people), represents a justified interest for Russia in view of Moscow efforts to implement the GEP strategy by strengthening the Eurasian integration, including the establishment of the long-term Russia-Pakistan cooperation, though, certainly, not at the expense of a time-tested partnership between Russia and India, but in balance with it. While observing this paradigm shift in Russia-Pakistan relations, the Indian side views it as "unlikely that Moscow would make any effort to shift from seeing India as its main partner in the South Asian region and also at the global level" [10]. 
Actually, Russia-Pakistan political dialog is aimed on achieving peace and stability in the region, so as to promote the sustainable economic development of its countries. Recent bilateral agreements on multidimensional cooperation which were concluded on December 8-12, 2019 between the RF and the IRP opened the new opportunities for the enhancement of interstate ties and private sector business activities, especially in energy, information technology, trade, transport, agriculture, industries and productions, science and technology. The Russian side, in particular, expressed intentions to invest up to $\$ 10$ billion in energy, information technology, railways and steel industries, including \$ 1 billion for the revival and modernization of Pakistan Steel Mills (PSM) in Karachi [11]. The said metallurgical complex is strategically located in the south-east of this megacity $(40 \mathrm{~km})$ in close vicinity to port Muhammed Bin Qasim. The costal site of Pakistan Steel lies on the National Highway and is linked to the railway network. The PSM was built and put into operation in 1985 with the assistance of the Soviet Union, which contributed much in laying foundation for iron and steel production in Pakistan by creating thus its national industry with the developed skill manpower.

In the Metallurgical Training Center (MTC) opened in 1978 the Soviet experts imparted training in various fields of electrical, chemical, mechanical, metallurgical technologies and electronics. The Soviet Vocational and Training system, education plan and curricular continues to be a base of the education process at the PSM Human Resource Development Department. The author of this article during her business mission to Pakistan in 1983-1984 through V/O "Tyazhpromexport" of the then USSR happened to be an immediate participant in all these events connected with the construction of the giant full-cycle metallurgical PSM complex, which became a symbol of pragmatic, mutually beneficial economic relations, despite the political confrontation between Moscow and Islamabad in those years due to the ongoing war in the neighboring Afghanistan.

The PSM earned operating profit from 1985 up to 2008 and registered a net profit in 13 years out of 23 years. But after bearing heavy losses mostly due to unchecked corruption and inefficient management, the Pakistan Steel was closed in 2015. It is rather regretful, that now the PSM is in a shutdown state which resulted in accumulated liabilities thus causing huge deficit issues for both the government and the metallurgical complex itself. Currently, the government of IRP has planned to revive PSM operation by adopting the "PublicPrivate Partnership" roadmap [12].

In this context the Russian side again extended cooperation to Pakistan on Still Mills revival and productivity increase. This offer among the others, mentioned above, was made during an official visit to Islamabad of the large, representative Russian delegation led by the RF Minister of Industry and Trade D. V. Manturov on December 8-12, 2019, who took part in the $6^{\text {th }}$ Session 
of the Russia-Pakistan Inter Government Commission (IGC) on Trade, Economic, Scientific and Technical Cooperation. In the framework of this session, the Russian participants identified energy cooperation between RF and IRP as a key area of "bilateral comprehensive strategic partnership" (cooperation in the construction of oil, gas and hydropower infrastructure, mineral exploration, hydrocarbon supplies, training of Pakistani industry specialists in Russian universities, etc.). The North-South main gas pipeline (MGP) was considered as the flagship project of Russia-Pakistan cooperation. Russia plans to invest $\$ 2.5$ billion in it [13]. The construction of this MGP infrastructure with the help of the advanced Russian technologies will provide gas pumping of about 12.4 billion cubic meters per year over a distance of 1,100 km from the southern Pakistani port cities Karachi and Gwadar, which are the main transport and energy links of CPEC, to Lahore city located in the North of the country [14].

On the sidelines of the $6^{\text {th }}$ IGC session attention was also paid to Russia participation in the construction of the Iran-Pakistan offshore gas pipeline with the supposed further extension of this route to India (IPI) in case of stabilizing the regional situation. The idea of its building was discussed for quite a long period of time (more than 20 years). However, the continuing contradictions and conflicts between the regional countries involved in it and the sanctions risks have long hindered the implementation of this economically profitable energy project for all the participating states. As for the representatives of the Russian Railways, they expressed their intentions to assist Pakistan in upgradation and modernization of the Quetta-Taftan railway line $(523 \mathrm{~km})$, which is strategically important for the regional connectivity. It is an integral part of one of the main railway lines ML-3 (Main Line - 3), which may be used as one more transport and economic corridor connecting Pakistan with the neighboring Iran, Turkey and further to Europe.

The Russian Federation considers Pakistan as the main country to link the Eurasian Economic Union with Asia, the Indian Ocean region and far beyond. The successful implementation of all the above mentioned joint projects demands improvement in the regional security of the Central and South Asia. Pakistan is viewed by Russia as one of the main players in stabilizing the regional situation and restoring peace in Afghanistan through the national reconciliation process by implementing the dialogue policy, including bilateral contacts with Moscow or "SCO - Afghanistan" contact group. What is more, Russia has recently intensified cooperation with Pakistan in the field of combating terrorism by arranging since 2016 several joint military exercises called "Friendship" (in Russian - "Druzhba") on a regular base and equipping the anti-terrorist Pakistani units with the helicopters.

Pakistan is among other SCO member-states, including neighboring India, who signed in 2017 the Convention on combating extremism and banning 
the terrorist and extremist groups. Both neighboring countries had already positive experience of participating together in a multinational counter-terror exercises "Peace Mission - 2018" under the SCO aegis. The joint maneuvers involved over 3,000 troops and 500 pieces of hardware. This Army Game was hold at Chebarkul in the Chelyabinsk region of Russia (August 22-29, 2018), where both Pakistani and Indian soldiers for the first time professionally and on people-to-people level interacted together with their other colleagues from SCO country-members. And it gave hope for a peaceful future in the unstable Central and South Asian region [15].

During the working visit to Pakistan on December 18-21, 2019, the Commander-in-Chief of the Russian Navy, Admiral N. A. Evmenov discussed the prospects for bilateral naval interaction, including exchange of delegations, cooperation in the field of naval vocational training and plans for joint activities to be held in 2020. He met with the leadership of the Pakistan defense Ministry at the IRP Naval Headquarters in Islamabad, and also visited the Pakistan Naval Academy, the Naval Military College and the naval base in Karachi [16].

Moscow and Islamabad close stance on the main issues of the global and regional agenda, including the formation of a common regional security structure, promotes intensification of their inter-state relations not only on the bilateral level, but on the multilateral scale of their cooperation in various international and regional organizations, including SCO and the EAEC. It is worth mentioning the military personal participation of Russia and Pakistan Armed Forces in the strategic command and staff exercise "Center-2019" (September 16-21, 2019) together with the military contingents from India, Kazakhstan, China, Kyrgyzstan, Tajikistan and Uzbekistan aimed at working out their military troops interaction in fighting international terrorism and ensuring military security in Central Asia. The practical stage of military exercises was held on the territory of three EAEC states: Russia, Kazakhstan and Kyrgyzstan. This joint military activities show serious intentions of all participating in it countries to form a common Eurasian security structure [17].

The option to conduct such SCO joint military exercises, in particular the counter-terror exercise "Peace mission-2020" at the Yurginsky training ground in the RF Kemerovo region (August 2020), was discussed during a meeting of the 9th Defense and Security Expert Working Group (EWG) of SCO. It was held on February 18-20, 2020 in Islamabad. The participants discussed main issues of cooperation between the defense ministries of SCO member-states and coordinated the plan of EWG activities for 2020 during Russia SCO Presidency. The parties also agreed to arrange the operational information exchange on security matters between the defense departments of SCO members [18]. The number of the military contingent participating in "Peace mission-2020" is planned to be about 10 thousand servicemen [19]. 
Thus, the intensification of interaction between RF and IRP both on bilateral and multilateral levels in the vector of enhancing economic and defense cooperation may be considered as a part of the general regionalization trend in the integration processes on the vast area of Eurasia, where the ongoing bilateral Russia-Pakistan projects, while facilitating practical implementation of the Russian GEP initiative, in the long term will have the option to transform into the emerging joint economic and security infrastructure of the Greater Eurasia aimed at promotion peace and sustainable socio-economic development for all belonging to it countries.

\section{References}

1. Message from the President to the Federal Assembly, December 3, 2015 / Poslaniye Prezidenta Federal'nomu Sobraniyu, 3 dekabrya 2015 g. (in Russian). URL: http://kremlin.ru/events/president/news/50864 (accessed 11.05.2020).

2. Proceedings of the Institute of Oriental studies, RAS, Issue 8: Pakistan: History and Current Problems/ed. by S. N. Kamenev. M.: IV RAN, 2018. 408 p. / Trudy Instituta vostokovedeniya RAN. Vypusk 8. Pakistan: istoriya i sovremennyye problemy (in Russian).

3. Golden Ring Economic Forum. URL: http://gref.org.pk/ (accessed 12.05.2020).

4. Proceedings of GREF-PIPS Joint Seminar on Golden Ring Economic Bloc for Regional Peace and National Economic Security. April 30, 2019. Islamabad, Lahore: GREF, 2019. P. 66.

5. Ibid. P. 72.

6. Serenko I. N. About the Prospects of China-Pakistan Economic Corridor Expansion // Eastern Analytics. 2019. № 1. P. 100-107. / K perspektive rasshireniya Kitayskopakistanskogo ekonomicheskogo koridora // Vostochnaya analitika.-2019. № 1. C. 100-107 (in Russian).

7. Shabbir Ahmed. Emerging Dynamics of the Race for Regional Integration // CPEC: A Precursor to Regional Economic Growth and Stability. Edit. by Zafar Iqbal Cheema. China Studies and Information Center (CSIC), Strategic Vision Institute (SVI). Islamabad. 2019. P. 211.

8. Ghulam Abbas. Pakistan clears $\$ 93.5 \mathrm{~m}$ to settle decades-old trade disputewith Russia. URL: https://profit.pakistantoday.com.pk/2020/02/26/pakistan-clears-93-5mto-settle-decades-old-trade-dispute-with-russia/ (accessed 12.05.2020).

9. Pakistan is interested in increasing the volume of investment from Russia, the country's ambassador to Russia Shafqat Ali Khan told TASS on Monday. Moscow, April 27, 2020. URL: https://tass.com/politics/1150439 (accessed 12.05.2020). 
10. Chandra Rekha. Emerging Trends in Russia-Pakistan Relations: Should India Be Concerned? URL:https://www.academia.edu/31555153/EMERGING_TRENDS_ IN_RUSSIA_-_PAKISTAN_RELATIONS_SHOULD_INDIA_BE_CONCERNED (accessed 15.06.2020).

11. Russia Pledges to Invest Billions in Pakistan. URL: https://russiabusinesstoday.com/ economy/russia-pledges-to-invest-billions-in-pakistan/ (accessed 07.04.2020).

12. Call for probe into 'deliberate destruction' of Steel Mills. URL: https://www. dawn.com/news/1557932/call-for-probe-into-deliberate-destruction-of-steelmills (accessed 15.06.2020).

13. Russia looks to invest in Pakistan in a big way. URL: http://www.ved.gov.ru/eng/ general/news/19/26239.html (accessed 16.06.2020).

14. Kamenev S. N. History of Economic Processes in Pakistan(20th - beginning of 21st Century) / Ed. by V.Y. Belokrenitsky. Institute of Oriental Studies, Russian Academy of Sciences. Moscow: IOS RAS, 2019. P. 336-337 / Kamenev. S. N. Istoriya ekonomicheskikh protsessov v Pakistane (XX - nachalo XXI v.) / Red. V. Y. Belokrenitskiy. Institut vostokovedeniya Rossiyskoy akademii nauk. M.: IV RAN, 2019 (in Russian).

15. Chiefs of SCO general staffs arrive at Peace Mission 2018 in Chelyabinsk region. URL: https://eng.mil.ru/en/news_page/country/more.htm?id=12193221@ egNews (accessed 16.06.2020).

16. The Commander-in-Chief of the Russian Navy concluded his working visit to Pakistan. URL: https://eng.mil.ru/en/structure/forces/navy/news/more. htm?id=12267915@egNews (accessed 15.06.2020).

17. Tsentr-2019 maneuvers. URL: http://eng.mil.ru/en/mission/practice/ tsentr-2019.htm (accessed 16.06.2020).

18. Pakistan hosts the 9th Defence and Security Expert Working Group meeting. URL: http://eng.sectsco.org/news/20200226/630180.html (accessed 16.06.2020).

19. About 10 thousand servicemen will take part in the anti-terrorist exercise "Peace mission-2020". URL: https://eng.mil.ru/en/news_page/country/more. htm?id=12280242@egNews (accessed 16.06.2020). 